Research Paper

\title{
N-cadherin Expression in Testicular Germ Cell and Gonadal Stromal Tumors
}

\section{Daniel J. Heidenberg 2 ,3, Joel H. Barton ${ }^{1}$, Denise Young ${ }^{3}$, Michael Grinkemeyer ${ }^{4}$, Isabell A. Sesterhenn ${ }^{1 凶}$}

1. Department of Genitourinary Pathology, Joint Pathology Center, Silver Spring, MD 20910, USA

2. Tulane University, New Orleans, LA 70118, USA

3. Center for Prostate Disease Research, Uniformed Services University of Health Sciences, Department of Surgery, Bethesda, MD 20814, USA

4. United States Air Force School of Aerospace Medicine, Aeromedical Research Dept. Wright-Patterson AFB, OH 45433, USA

$\triangle$ Corresponding author: Isabell A. Sesterhenn, Department of Genitourinary Pathology, Joint Pathology Center, Silver Spring, MD 20910, USA

(C) Ivyspring International Publisher. This is an open-access article distributed under the terms of the Creative Commons License (http://creativecommons.org/ licenses/by-nc-nd/3.0/). Reproduction is permitted for personal, noncommercial use, provided that the article is in whole, unmodified, and properly cited.

Received: 2012.08.10; Accepted: 2012.09.01; Published: 2012.09.11

\begin{abstract}
Neural-cadherin is a member of the cadherin gene family encoding the $\mathrm{N}$-cadherin protein that mediates cell adhesion. $\mathrm{N}$-cadherin is a marker of Sertoli cells and is also expressed in germ cells of varying stages of maturation. The purpose of this study was to determine the presence and distribution of this protein by immunohistochemistry in 105 germ cell tumors of both single and mixed histological types and 12 gonadal stromal tumors. Twenty-four germ cell tumors consisted of one cell type and the remaining were mixed. Of the 23 seminomas in either pure or mixed tumors, $\mathbf{7 4 \%}$ were positive. Two spermatocytic seminomas were positive. Of the 83 cases with yolk sac tumor, $99 \%$ were positive for $\mathrm{N}$-cadherin. The teratomas were positive in $73 \%$ in neuroectodermal and / or glandular components. In contrast, $87 \%$ of embryonal carcinomas did not express $\mathrm{N}$-cadherin. Only $17 \%$ of the syncytiotrophoblastic cells were positive for $\mathrm{N}$-cadherin. In conclusion, $\mathrm{N}$-cadherin expression is very helpful in the identification of yolk sac tumors. In addition to glypican-3 and Sal-like protein 4, N-cadherin can be beneficial for the diagnosis and classification of this subtype of testicular germ cell tumor. Nine of the 12 gonadal stromal tumors were positive to a variable extent.
\end{abstract}

Key words: N-cadherin, testis, germ cell tumors, gonadal stromal tumors.

\section{Introduction}

The neural-cadherin $(\mathrm{CDH} 2)$ gene encodes the $\mathrm{N}$-cadherin protein, a member of the cadherin gene family that mediates cell adhesion, differentiation, embryogenesis, and invasion ${ }^{1}$. It has been described in a number of organs ${ }^{1,2}$ and malignancies derived from these ${ }^{3,4,5}$. Although the distribution of $\mathrm{N}$-cadherin in the normal testis is known ${ }^{6}$, there is no information regarding its presence in testicular germ cell and gonadal stromal tumors. The purpose of this study was to determine the presence and distribution of this protein in testis tumors compared to the distribution in the immature and mature testis.

\section{Materials and Methods}

\section{Specimens}

The testis of one 32-week-old fetus and orchiectomy specimens of 105 patients with germ cell tumors as well as 12 gonadal stromal tumors from the Testicular Tumor Registry of the Armed Forces Institute of Pathology were used. The specimens were fixed in $10 \%$ neutral buffered formalin and paraffin embedded. The tumors were classified according to the 2004 World Health Organization classification ${ }^{7}$. The H\&E stained sections of each patient were reviewed and 1 representative section per case was selected for this 
study. The corresponding unstained section was utilized for immunohistochemical evaluation of $\mathrm{N}$-cadherin.

\section{Immunohistochemistry}

Following deparaffinization, the sections were dehydrated and blocked in $0.6 \%$ hydrogen peroxide in methanol for 20 minutes. Sections were processed for antigen retrieval in citrate buffer $(\mathrm{pH}$ 6.0) for 25 minutes in a microwave followed by 25 minutes of cooling in room temperature. Sections were then blocked in 1\% horse serum for 40 minutes, followed by incubation with commercial monoclonal mouse anti-human N-cadherin clone 6G11, isotype $\mathrm{IgG}_{1}$, kappa (DAKO Cytomation, Inc., Carpinteria, CA) as the primary antibody at a dilution of $1: 120$ for 60 minutes at room temperature. Following primary antibody incubation, sections were incubated with the biotinylated horse anti-mouse antibody at a dilution of 1:200 (Vector Burlingame) for 30 minutes followed by treatment with the $\mathrm{ABC}$ Kit (Vector) for 30 minutes. The color detection was achieved by treatment with VIP (Vector) for 5 minutes. Sections were counterstained in hematoxylin for 1 minute, dehydrated, cleared and mounted. Positive reaction for $\mathrm{N}$-cadherin was scored as membranous, cytoplasmic or cytoplasmic and membranous and recorded. The percentage of cells positive was scored: up to $25 \%$, > $25 \%-50 \%$, > 50\%-75\%, and $>75 \%$. The staining intensity was scored as 1+ (weak), 2+ (moderate), or 3+ (strong).

\section{Results}

The distribution of tumor types is shown in Table 1 . The percentage of cells positive and intensity of staining for $\mathrm{N}$-cadherin are seen in Table 2 for tumors of one histological type and in Table 3 for tumors of more than histological type. In the normal testis, $\mathrm{N}$-cadherin was consistently seen in a membranous pattern in Sertoli cells of the immature (Fig. 1A, 1B) and mature testis (Fig. 2A, 2B), and served as a built-in positive control. It was also detected in a similar pattern in the rete (Fig. 1A, 1B) of the immature and mature testis. However, N-cadherin expression was limited to the proximal portion of the epididymis (Fig. 3A, 3B) in the adult. The distal part of the epididymis and the vas were negative for $\mathrm{N}$-cadherin as were normal stromal components including smooth muscle and endothelial cells. Occasionally, Leydig cells were diffusely positive. In sections that included the mesothelial surface, N-cadherin was positive in mesothelial cells. The $\mathrm{N}$-cadherin expression detected in spermatogonia of the immature testis (Fig. 1A, 1B) and spermatogonia and spermatocytes of the adult testis is difficult to separate from the associated Sertoli cells. The unclassified type of intratubular germ cell neoplasia also has membranous positivity with $2+$ intensity (Fig. 2A, 2B). Six of the 8 pure seminomas and 11 of 15 seminomatous components in mixed germ cell tumors were positive in a characteristic linear, "zipper-like" pattern restricted to areas of cell to cell adhesion referred to as a "junctional pattern" (Fig. $4 \mathrm{~A}, 4 \mathrm{~B})$. At the interface between tumor cells and stroma, N-cadherin was usually absent. In most of the seminomas, $\mathrm{N}$-cadherin was observed in less than $50 \%$ of cells with $2+$ intensity (Tables 2 and 3 ). In the two spermatocytic seminomas, the $\mathrm{N}$-cadherin was identified in a membranous pattern with moderate intensity in $25 \%$ to $50 \%$ of tumor cells (Fig. 5A, 5B). Six pure yolk sac tumors (Fig. 6A, 6B) and all but one of yolk sac tumor components in 76 mixed germ cell tumors (Fig. 8A, 8B) were positive for $\mathrm{N}$-cadherin. The staining was membranous and cytoplasmic and mainly $3+$ intensity. In only 8 of 67 mixed tumors, foci of embryonal carcinoma were focally 1 to $2+$ positive for N-cadherin (Fig. 7A, 7B, Table 3). In three pure embryonal carciomas, one was weakly and only focally positive (Fig. 7C, 7D, Table 2). Of 3 pure teratomas, 2 were positive for $\mathrm{N}$-cadherin, and in 57 mixed tumors with teratoma, 42 were positive for $\mathrm{N}$-cadherin in neuroectodermal elements, glial cells, or glandular epithelium (Fig. 9A, 9B). The intensity was mainly moderate $(2+)$. The 3 cases with foci of choriocarcinoma were negative as were the syncytiotrophoblastic cells in 20 of the 24 cases. Yolk sac tumor was by far the most consistently and strongly immunoreactive germ cell tumor type.

Three of the four Leydig cell tumors showed weak cytoplasmic reactivity (Fig. 10A,10B). Four of the six Sertoli cell tumors were positive with weak to moderate membranous staining (Fig.11A, 11B) and one with Leydig and Sertoli cell differentiation in membranous and cytoplasmic pattern. The juvenile granulosa cell tumor showed mainly weak cytoplasmic positivity. (Table 4, Fig 12A, 12B).

\section{Discussion}

The distribution of N-cadherin in the immature and mature testis in this study is similar to that reported by others ${ }^{2}, 6$. Considering the origin of these tumors from the primordial germ cell ${ }^{8,9}, \mathrm{~N}$-cadherin expression in the unclassified type of intratubular germ cell neoplasia and all of the basic germ cell tumor types of the adult is not surprising. The membranous, junctional expression pattern in seminoma reflects the close relationship between seminoma and both the intratubular unclassified type of germ cell neoplasia and the primordial germ cell. The sper- 
matocytic seminoma stains in a pattern similar to the spermatocytes of the adult testis. The preferential staining of glandular and neuroectodermal teratomatous elements is consistent with the $\mathrm{N}$-cadherin expression in tissues of neuroectodermal ${ }^{10}$ and endodermal origin ${ }^{2}$. The embryonal carcinoma has features of an undifferentiated carcinoma and the $\mathrm{N}$-cadherin expression is infrequent, less organized, and very limited. It is possible that the absence of $\mathrm{N}$-cadherin in embryonal carcinoma reflects a lack of differentiation ${ }^{11}$. In this study, the $\mathrm{N}$-cadherin expression in $98.7 \%$ (82 of 83 ) of yolk sac tumor samples was the most consistent. All but one case, which contained a minute focus of yolk sac tumor, stained intensely positive for $\mathrm{N}$-cadherin in the majority, highlighting the different histologic patterns. It was not only membranous but also cytoplasmic. More than half of adult testicular germ cell tumors consist of more than one cell type. Appropriate medical management depends on accurate pathologic diagnosis and tumor classification. Yolk sac tumor is present in approximately $40 \%$ of mixed germ cell tumors but may be difficult to recognize because it displays several microscopic patterns. In about $75 \%$ to $90 \%$ of cases, $\alpha$-fetoprotein can be detected in the serum or by positive staining in the tumor. The focal positivity can make it difficult to identify and differentiate the yolk sac tumor component. As such, additional markers of endodermal differentiation would be beneficial for the diagnosis and classification of these tumors. Therefore, $\mathrm{N}$-cadherin could be a useful additional marker for the detection of even minute foci of yolk sac tumor in the setting of a mixed germ cell tumor, which can be easily overlooked in H\&E stained sections. Compared to N-cadherin, AFP is present in $92 \%$ of yolk sac tumors, only focally and less extensive. Another excellent marker, helpful to identify minute yolk sac tumor elements, is glypican-3 (GPC3) 12, 13, 14, 15. Sal-like protein 4 (SALL4), a stem cell marker, is positive in all germ cell tumor types and is more sensitive in detecting YST than AFP or GPC3, similar to $\mathrm{N}$-cadherin ${ }^{16,17}$. Unlike SALL4, the embryonal carcinomas were only rarely and focally positive for $\mathrm{N}$-cadherin. The solid YST can resemble a seminoma in the H\&E stained sections, but the characteristic linear positivity differs strikingly from the membranous and cytoplasmic pattern in YSTs. In metastatic cases, there was one yolk sac tumor and one teratoma. Both stained positive for N-cadherin with the YST staining $>75 \% / 3+$ and the teratoma staining 50\%/2+. This demonstrates that $\mathrm{N}$-cadherin is useful for identifying metastatic cancers as well.

In contrast to the strong membranous reactivity for N-cadherin in immature and mature Sertoli cells, the reaction in Sertoli cell tumors is generally membranous, but weak and heterogeneous. In Leydig cell tumors, we found focal membranous and cytoplasmic reactivity. The juvenile granulosa cell tumor reacted focally and with varying intensity.

$\mathrm{CDH} 2$ expression in testicular tumors is not restricted to the germ cell tumor variants but is also observed in gonadal stromal tumors albeit more limited and less intense. The strong and consistent positive reaction for $\mathrm{N}$-cadherin in yolk sac tumor was unexpected and potentially helpful.

\section{Acknowledgments}

The authors greatly appreciate the expertise of Donald F. Cameron, University of South Florida, for his advice regarding Sertoli cells and their tumors. We also would like to thank Stephen Doyle of the Center for Prostate Disease Research for his assistance with the figures and tables.

\section{Notes}

The opinions and assertions contained herein represent the personal views of the authors and are not to be construed as official or as representing the views of the Department of the Army, the Department of Defense, or the United States Government.

\section{Abbreviations}

YST: Yolk sac tumor; AFP: a fetoprotein; SALL4: Sal-like protein 4; GPC3: glypican-3.

\section{Competing Interests}

The authors have declared that no competing interest exists.

\section{References}

1. Derycke LD, Bracke M.E. N-cadherin in the spotlight of cell-cell adhesion, differentiation, embryogenesis, invasion, and signalling. Int J Dev Biol. 2004; 48: 463-476.

2. Tsuchiya B, Sato Y, Kameya T, Okayasu I, Mukai K. Differential expression of N-cadherin and E-cadherin in normal human tissues. Arch Histol Cytol. 2006; 69: 135-145.

3. Daraï E, Scoazec JY, Walker-Combrouze F, et al. Expression of cadherins in benign, borderline, and malignant ovarian epithelial tumors: A Clinicopathologic Study of 60 Cases. Hum Pathol. 1997; 28: 922-8.

4. Nagi C, Guttman M, Jaffer S et al. N-cadherin expression in breast cancer: correlation with an aggressive histologic variant - invasive micropapillary carcinoma. Breast Cancer Res Treat. 2005; 94: 225-235.

5. Mosnier JF, Kande C, Cazals-Hatem D, et al. N-cadherin serves as diagnostic biomarker in intraheptic and perihilar cholangiocarcinomas. Mod Pathol. 2009; 22: 182-190.

6. Andersson AM, Edvarsen K, Skakkeback NE. Expression and localization of N- and E-cadherin in human testis and epididymis. Int J Androl. 1994; 17:174-180.

7. Eble J, Sauter G, Epstein J, Sesterhenn IA. World Health Organization classification of tumours, pathology and genetics, tumours of the urinary system and male genital organs. Lyon, France: IARC Press; 2004.

8. Krausz C, Looijenga LH. Genetic aspects of testicular germ cell tumors. Cell Cycle 2008; 7:3519-3524.

9. Looijenga LH, Gillis AJ, Stoop HJ, et al. Chromosomes and expression in human testicular germ cell tumors: insight into their cell of origin and pathogenesis. Ann N Y Acad Sci 2007; 1120:187-214. 
10. Takeichi M. Cadherin cell adhesion receptors as a morphogenetic regulator. Science. 1991; 251: 1451-1455.

11. Eastham AM, Spencer H, Soncin F, et al. Epithelial-mesenchymal transition events during human embryonic stem cell differentiation. Cancer Res. 2007; 67: 11254-11262.

12. Zynger D, McCallum JC, Luan C, et al. Glypican 3 has a higher sensitivity than alpha-fetoprotein for testicular and ovarian yolk sac tumour: immunohistochemical investigation with analysis of histological growth patterns. Histopathology 2010; 56: 750-757.

13. Zynger DL, Dimov ND, Luan C, et al. Glypican 3: a novel marker in testicular germ cell tumors. Am J Surg Pathol 2006; 30: 1570-1575.
14. Ota S, Hishinuma M, Yamauchi N, et al. Oncofetal protein glypican-3 in testicular germ-cell tumor. Virchows Arch 2006; 449: 308-314.

15. Esheba GE, Pate LL, Longacre TA. Oncofetal protein glypican-3 distinguishes yolk sac tumor from clear cell carcinoma of the ovary. Am J Surg Pathol 2008; 32: 600-607.

16. Cao D, Li J, Guo S, et al. SALL4 is a novel diagnostic marker for testicular germ cell tumors. Am J Surg Pathol 2009; 33: 1065-1077.

17. Mostofi FK, Sesterhenn IA, Davis CJ Jr. Immunopathology of germ cell tumors of the testis. Semin Diagn Pathol 1987; 4: 320-341.

\section{Tables and Figures}

Table I. Frequency of Histological Tumor Types.

\begin{tabular}{|c|c|}
\hline Tumor Type & Number \\
\hline Seminoma & 8 \\
\hline Yolk Sac Tumor (1 metastatic) & 7 \\
\hline Teratoma (1 metastatic) & 4 \\
\hline Embryonal Carcinoma & 3 \\
\hline Spermatocytic Seminoma & 2 \\
\hline Yolk Sac Tumor, Embryonal Carcinoma, Teratoma & 22 \\
\hline Yolk Sac Tumor, Embryonal Carcinoma, Teratoma, Syncytiotrophoblasts & 14 \\
\hline Yolk Sac Tumor, Embryonal Carcinoma & 12 \\
\hline Yolk Sac Tumor, Teratoma & 9 \\
\hline Yolk Sac Tumor, Embryonal Carcinoma, Syncytiotrophoblasts & 4 \\
\hline Yolk Sac Tumor, Embryonal Carcinoma, Teratoma, Seminoma & 3 \\
\hline Yolk Sac Tumor, Teratoma, Seminoma, & 3 \\
\hline Yolk Sac Tumor, Embryonal Carcinoma, Seminoma, Syncytiotrophoblasts & 3 \\
\hline Yolk Sac Tumor, Embryonal Carcinoma, Seminoma & 2 \\
\hline Yolk Sac Tumor, Embryonal Carcinoma, Teratoma, Seminoma, Syncytiotrophoblasts & 2 \\
\hline Seminoma, Embryonal Carcinoma & 2 \\
\hline Yolk Sac Tumor, Teratoma, Choriocarcinoma & 1 \\
\hline Yolk Sac Tumor, Embryonal Carcinoma, Choriocarcinoma & 1 \\
\hline Teratoma, Syncytiotrophoblasts & 1 \\
\hline Embryonal Carcinoma, Teratoma, Choriocarcinoma & 1 \\
\hline Embryonal Carcinoma, Teratoma & 1 \\
\hline Sertoli Cell Tumor & 6 \\
\hline Leydig Cell Tumor & 4 \\
\hline Sertoli- Leydig Cell Tumor & 1 \\
\hline Juvenile Granulosa Tumor & 1 \\
\hline
\end{tabular}

Table 2. N-cadherin Expression in Pure Germ Cell Tumors.

\begin{tabular}{|c|c|c|c|c|c|c|c|c|}
\hline \multirow{2}{*}{$\begin{array}{l}\text { Tumor } \\
\text { Pure Tumors }\end{array}$} & \multicolumn{5}{|c|}{ Extent of Tumor Positive (no. of tumors) } & \multicolumn{3}{|c|}{ Intensity of Staining } \\
\hline & 0 & $1-25 \%$ & $26-50 \%$ & $51-75 \%$ & $76-100 \%$ & $1+$ & $2+$ & $3+$ \\
\hline Seminoma (8) & 2 & 5 & 1 & 0 & 0 & 2 & 4 & 0 \\
\hline Yolk Sac Tumor (6) & 0 & 0 & 0 & 0 & 6 & 0 & 0 & 6 \\
\hline Teratoma $(3)^{*}$ & 1 & 1 & 1 & 0 & 0 & 1 & 1 & 0 \\
\hline Spermatocytic Seminoma (2) & 0 & 0 & 2 & 0 & 0 & 0 & 2 & 0 \\
\hline Embryonal Carcinoma (3) & 2 & 1 & 0 & 0 & 0 & 1 & 0 & 0 \\
\hline
\end{tabular}

* Due to the glandular and glial staining of teratoma, we were unable to calculate percentage of tumor stained. 
Table 3. N-cadherin Protein Expression in Mixed Germ Cell Tumors.

\begin{tabular}{|c|c|c|c|c|c|c|c|c|}
\hline Tumor & Exten & umor $\mathrm{P}$ & e (no. of & & & Int & of $S t$ & \\
\hline Mixed Germ Cell Tumors & 0 & $1-25 \%$ & $26-50 \%$ & $51-75 \%$ & $76-100 \%$ & $1+$ & $2+$ & $3+$ \\
\hline Yolk Sac Tumor (76) & 1 & 10 & 6 & 10 & 49 & 8 & 16 & 51 \\
\hline Embryonal Carcinoma (67) & 59 & 8 & 0 & 0 & 0 & 4 & 3 & 1 \\
\hline Teratoma* $(57)$ & 15 & 0 & 0 & 0 & 0 & 16 & 18 & 8 \\
\hline Seminoma (15) & 4 & 5 & 4 & 0 & 2 & 4 & 7 & 0 \\
\hline Choriocarcinoma (3) & 3 & 0 & 0 & 0 & 0 & 0 & 0 & 0 \\
\hline Syncytiotrophoblasts (24) & 20 & 4 & 0 & 0 & 0 & 4 & 0 & 0 \\
\hline
\end{tabular}

* Due to the glandular and glial staining of teratoma, we were unable to calculate percentage of tumor stained.

Table 4. N-cadherin Expression in Stromal Tumors.

\begin{tabular}{lccccccc}
\hline Tumor & \multicolumn{3}{c}{ Extent of Tumor Positive (no. of tumors) } & \multicolumn{3}{c}{ Intensity of Staining } \\
\hline Stromal Tumors & 0 & $1-25 \%$ & $26-50 \%$ & $51-75 \%$ & $76-100 \%$ & $1+$ & $2+$ \\
Sertoli Cell Tumor (6) & 2 & 3 & 1 & 0 & 0 & 3 & 1 \\
Leydig Cell Tumor (4) & 1 & 3 & 0 & 0 & 0 & 3 & 0 \\
\hline
\end{tabular}

\section{$1 \mathrm{~A}$}
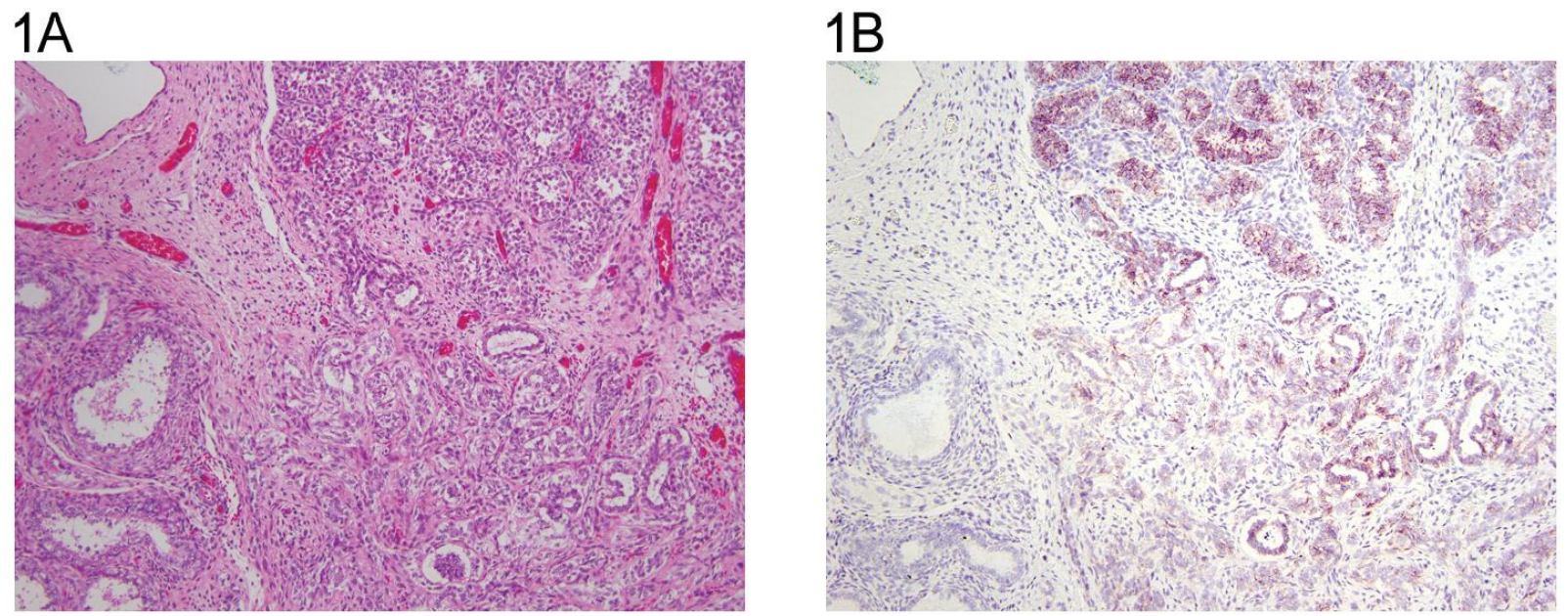

Fig. I. A: Immature testis with seminiferous tubules in the upper half and rete in the lower half $(H \& E \times 10)$. B same field (anti N-cadherin $\times 10)$. Sertoli cells and rete epithelium are positive in a membranous pattern. Some of the spermatogonia may also be positive.
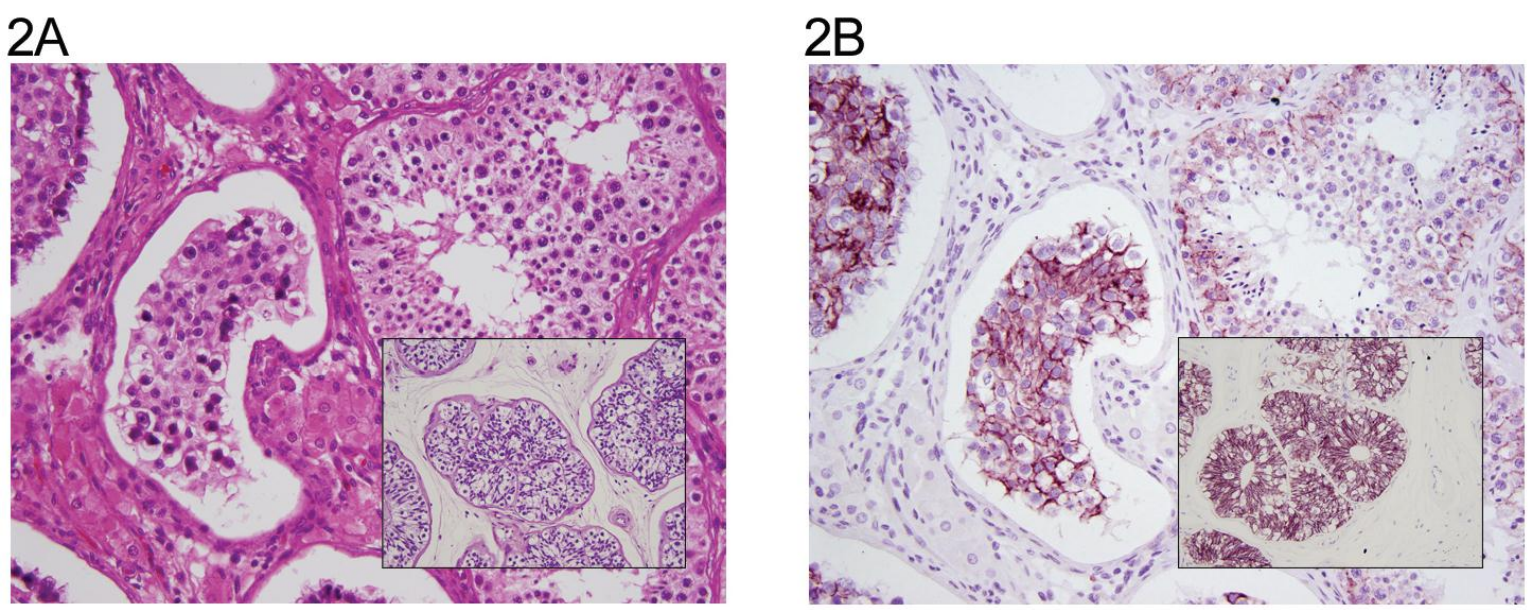

Fig. 2. A: Adult testis $(H \& E \times 20)$. On the right seminiferous tubules with spermatogenesis are seen. The left shows a tubule with intratubular germ cell neoplasia unclassified. The Leydig cells are prominent. The insert shows persistent immature tubules lined by strongly positive Sertoli cells ( H\&E $x$ 40). B: same field (anti-N-cadherin $\times 20$ ). Sertoli cells are positive, and a number of spermatogonia and spermatocytes may be positive. The intratubular malignant germ cells and the Sertoli cells have a membranous reaction. The Leydig cells are negative. The insert shows persistent immature tubules lined by strongly positive Sertoli cells (anti N-cadherin $\times 40$ ). 
$3 \mathrm{~A}$

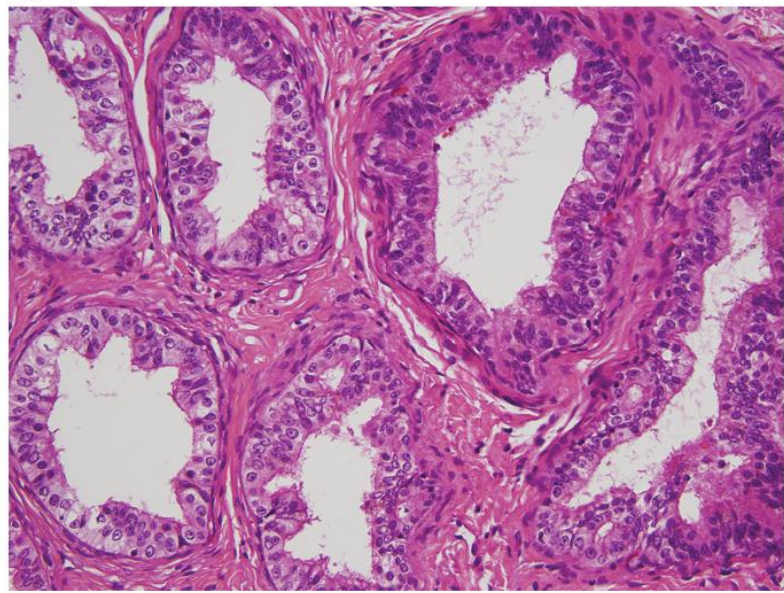

3B

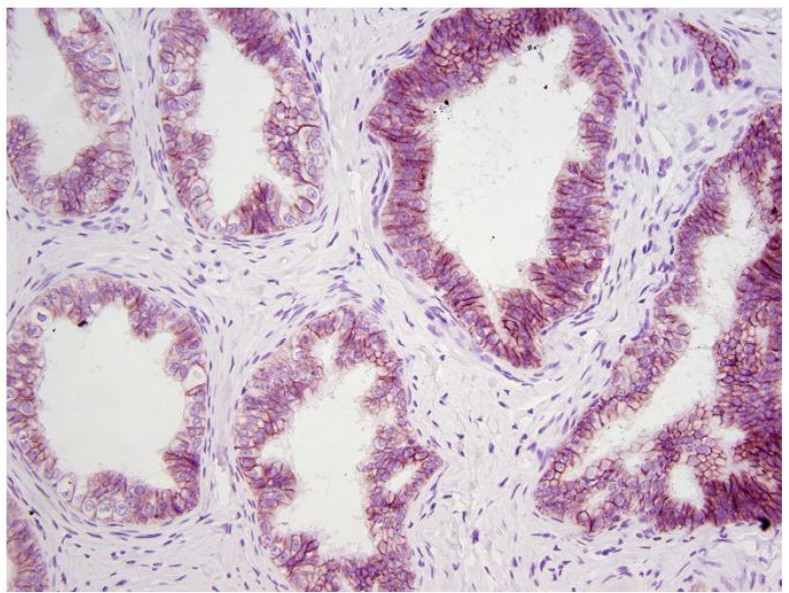

Fig. 3. A: Epididymal ducts (H\&E x 20). B: same field (anti N-cadherin $\times 20)$. Epithelial cells with membranous reactivity.

$4 \mathrm{~A}$

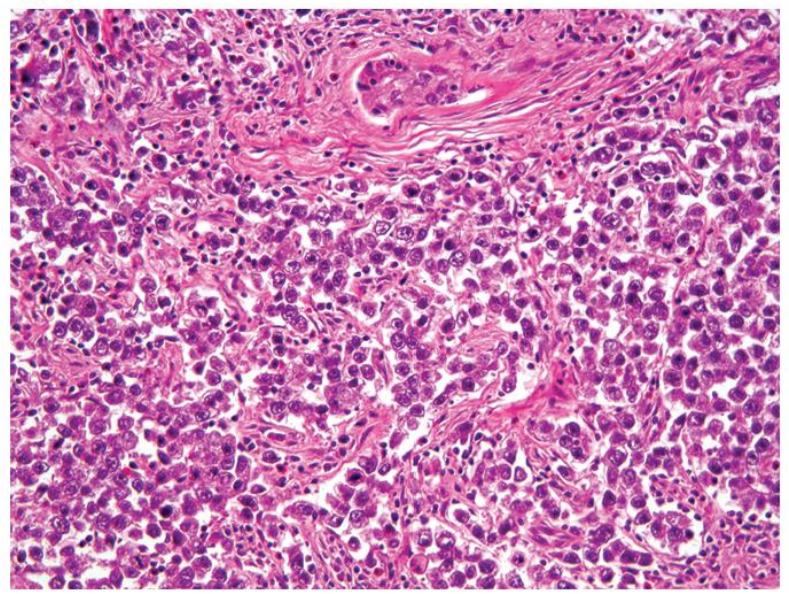

4B

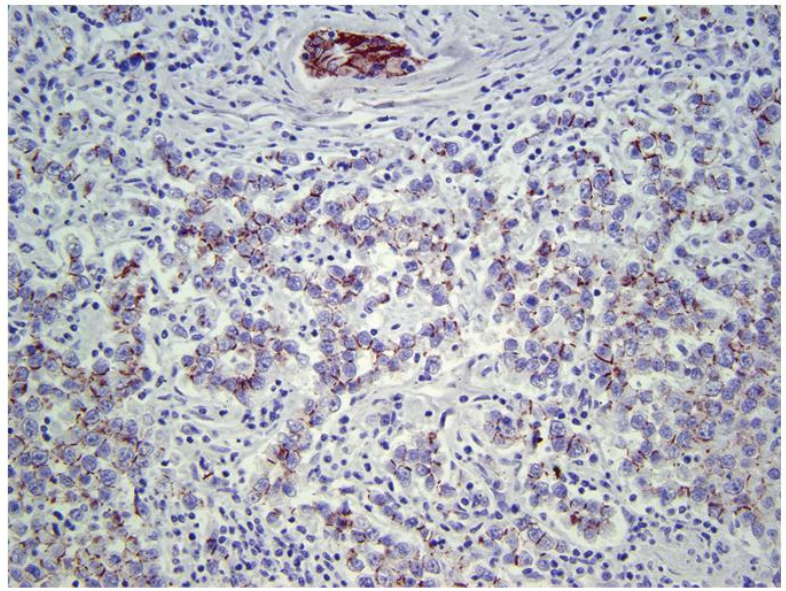

Fig. 4. A: Seminoma with entrapped seminiferous tubule in upper center $(H \& E \times 20)$. B: same field (anti $N$-cadherin $\times 40)$. The tumor cells show a linear zipper-like positive reaction.
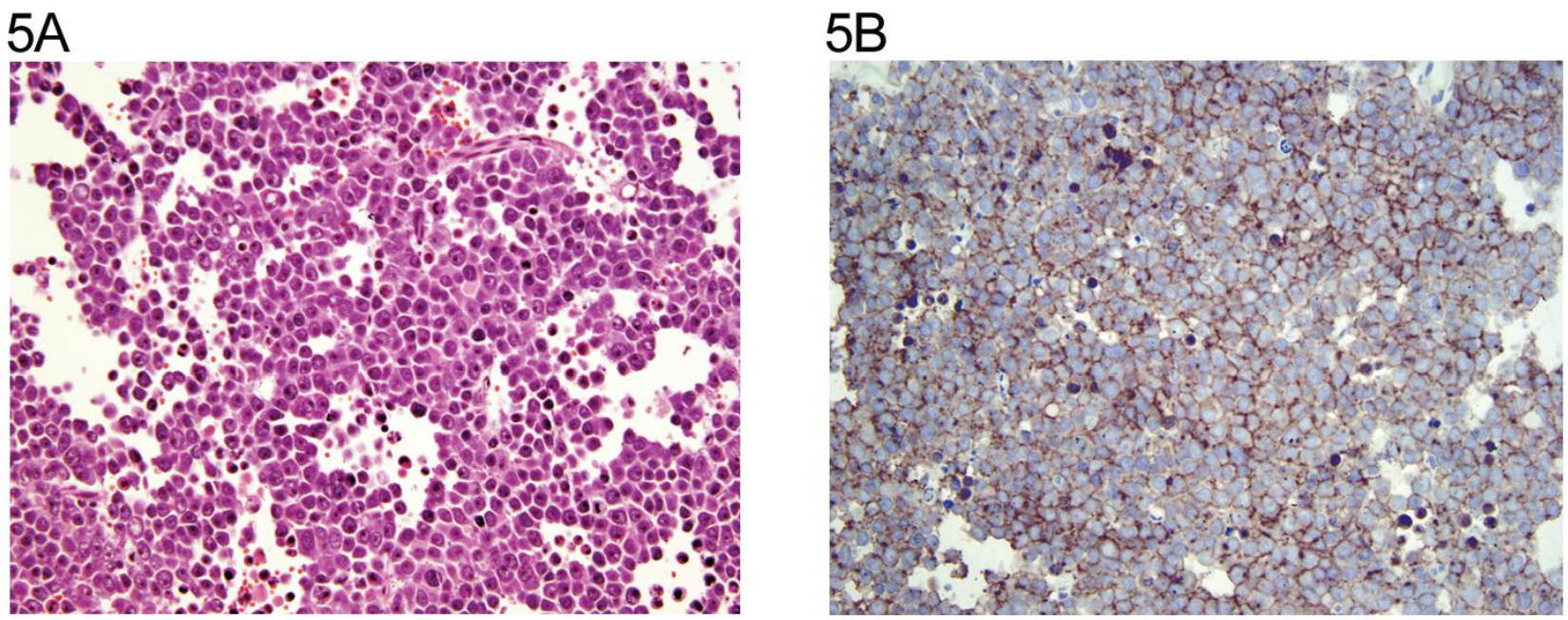

Fig. 5. A: Spermatocytic seminoma (H\&E x 20). B: same field (anti N-cadherin $\times 20)$. Many of the tumor cells show the zipper-like membranous staining. 
$6 \mathrm{~A}$

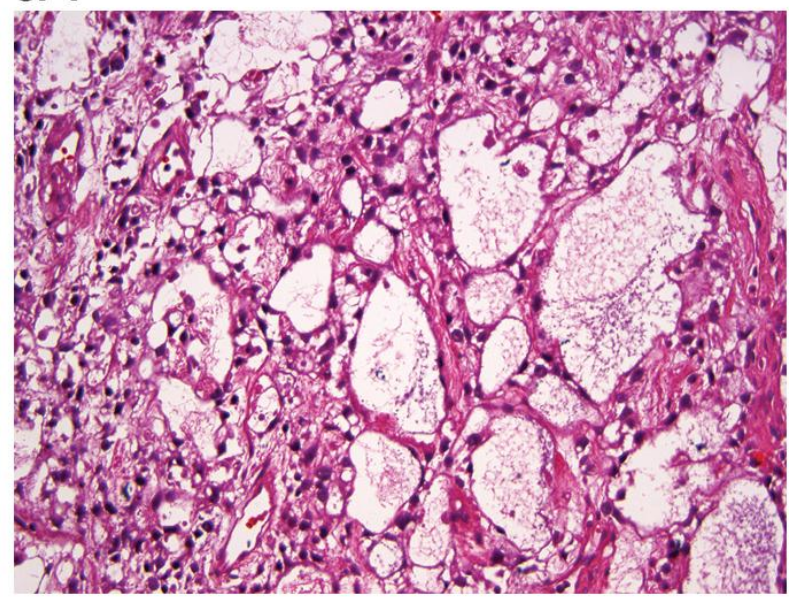

$6 \mathrm{~B}$

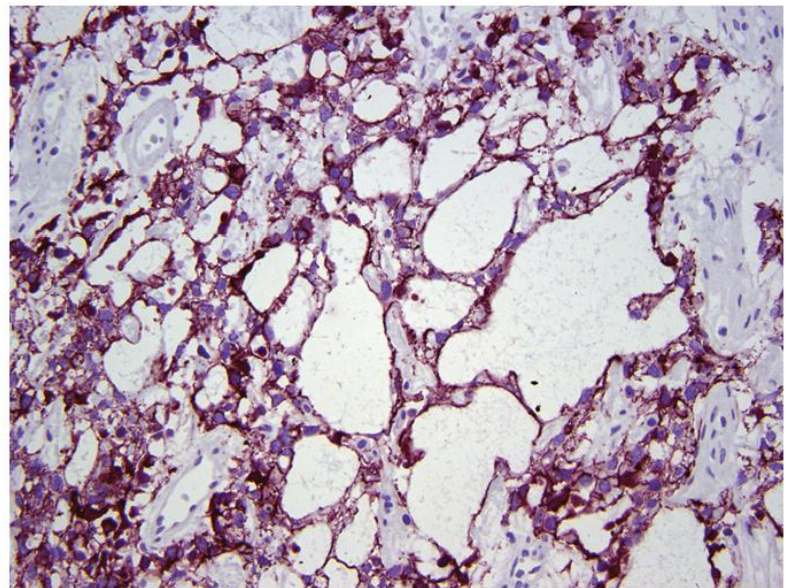

Fig. 6. A: Yolk sac tumor with reticular and microcystic growth pattern (H\&E stain $\times 20$ ). B: same field (anti N-cadherin $\times 20$ ). The tumor cells show cytoplasmic and membranous staining.

$7 \mathrm{~A}$

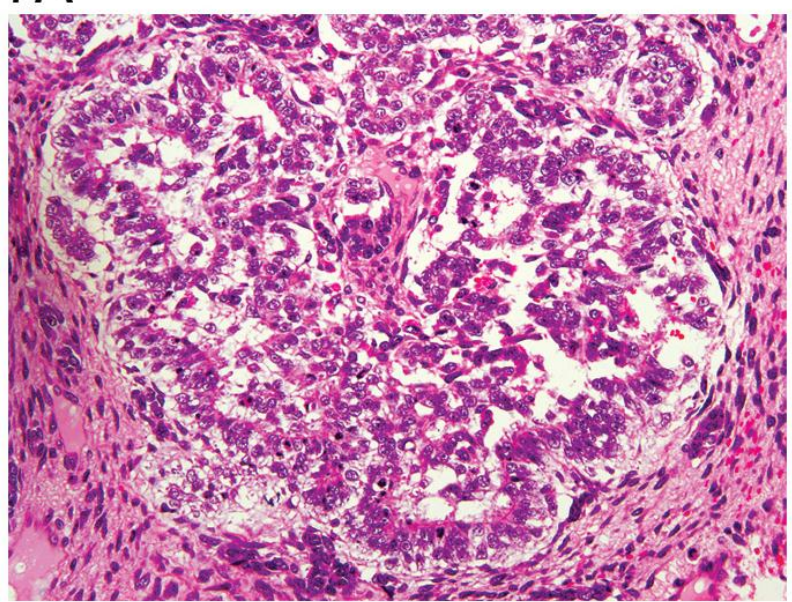

$7 \mathrm{C}$

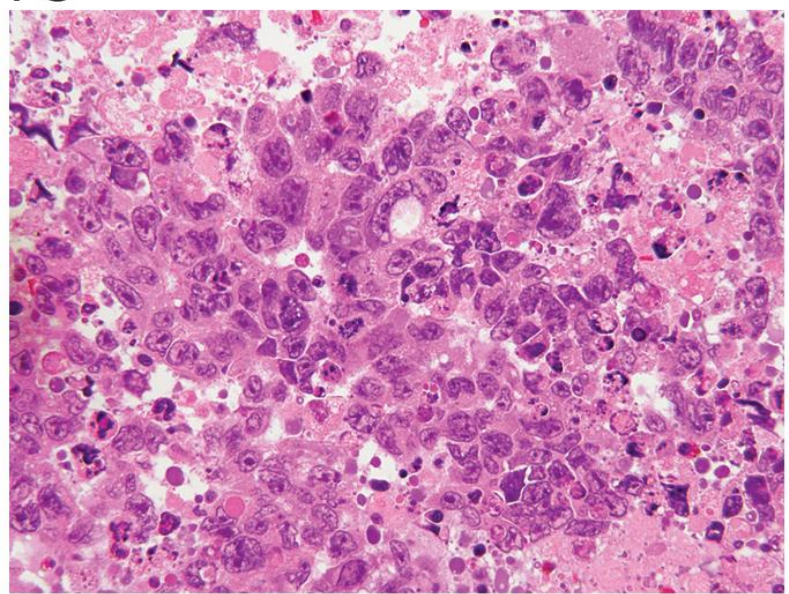

\section{$7 \mathrm{~B}$}

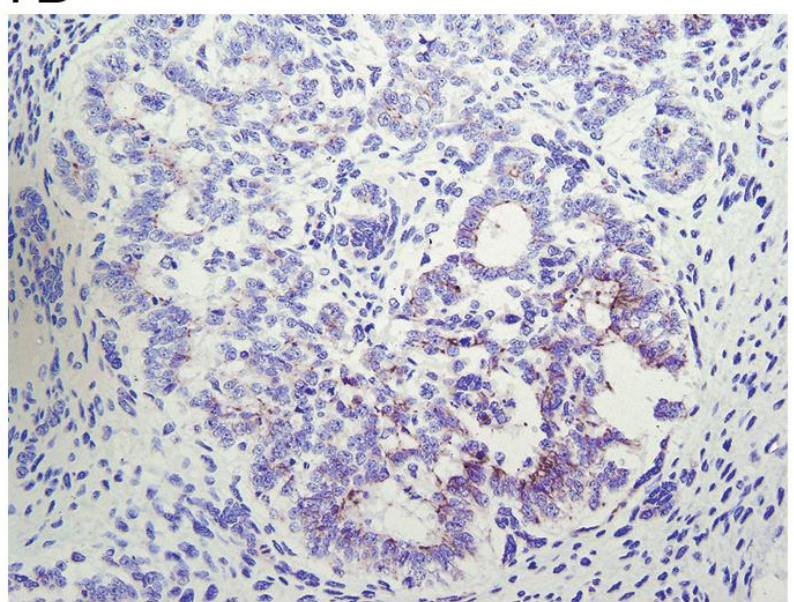

7D

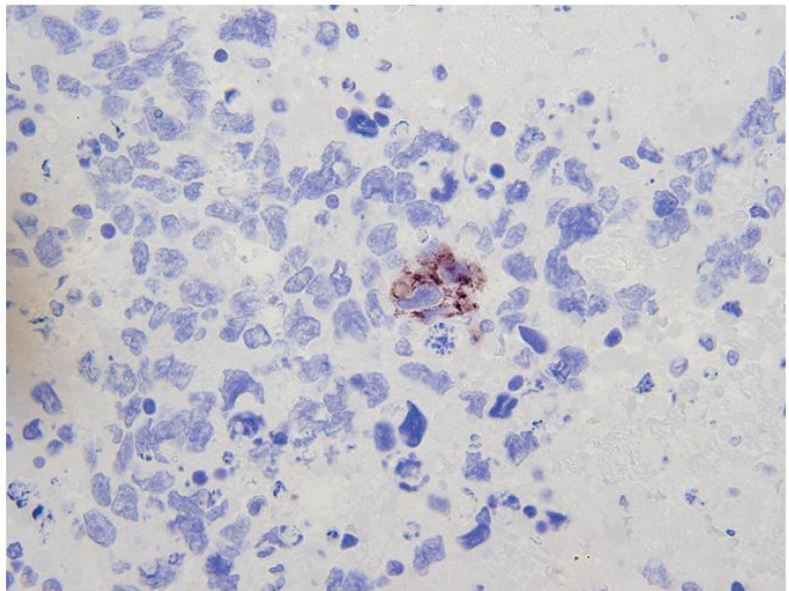

Fig. 7. A: Embryonal carcinoma (H\&E x 20). B: same field (anti N-cadherin $\times 20$ ). A number of tumor cells show cytoplasmic and membranous reactivity. C: Embryonal carcinoma (H\&E x 40). D: same field (anti N-cadherin x 40). A small cluster of tumor cells shows "disorganized" incomplete partial cytoplasmic and membranous reactivity. 

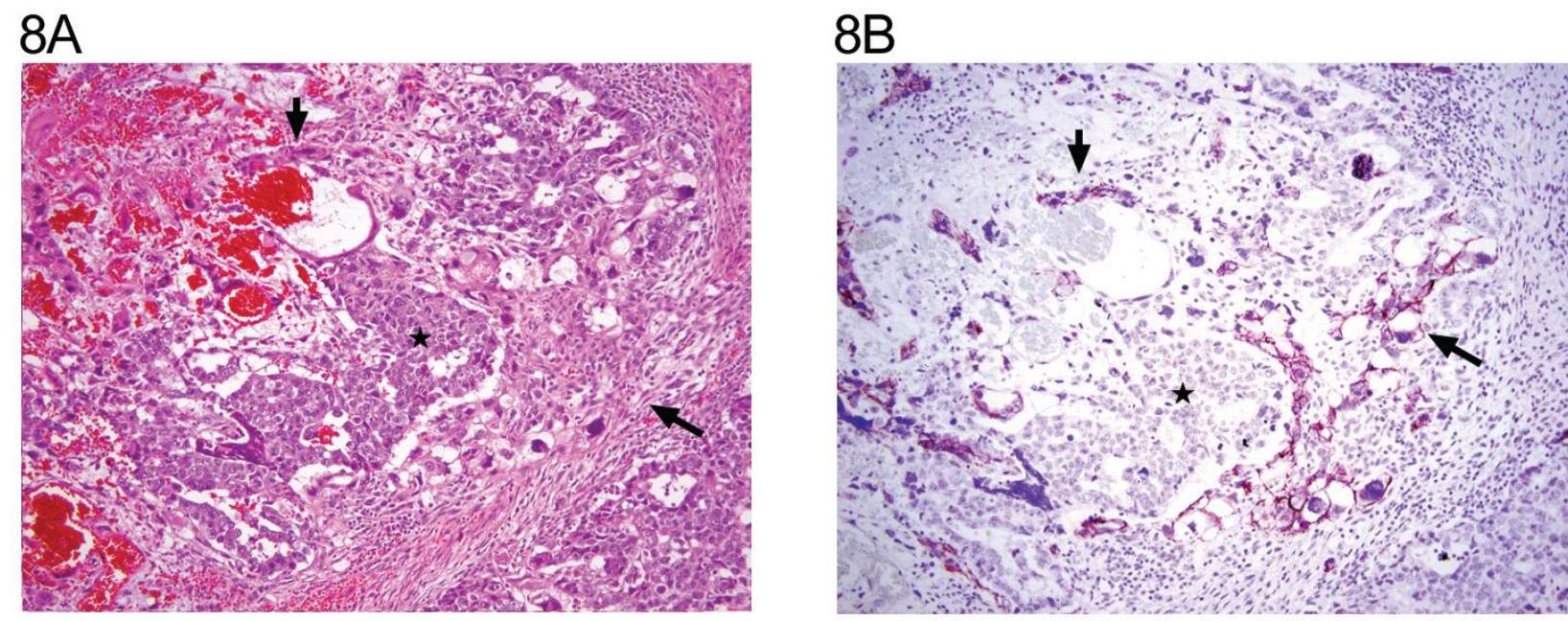

Fig. 8. A: The tumor consists of embryonal carcinoma (*), yolk sac tumor (long arrow), and syncytiotrophoblastic cells (short arrow) (H\&E $\times 20)$. B: same field $(\mathrm{N}$-cadherin $\times 20)$. The embryonal carcinoma $(*)$ is negative, whereas the yolk sac tumor elements (long arrow) and some of the syncytiotrophoblastic cells (short arrow) are positive.

\section{A}

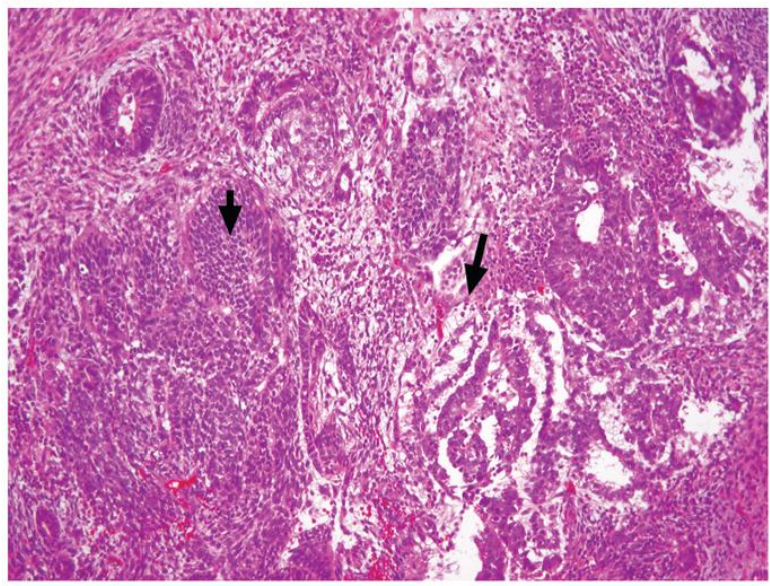

9B

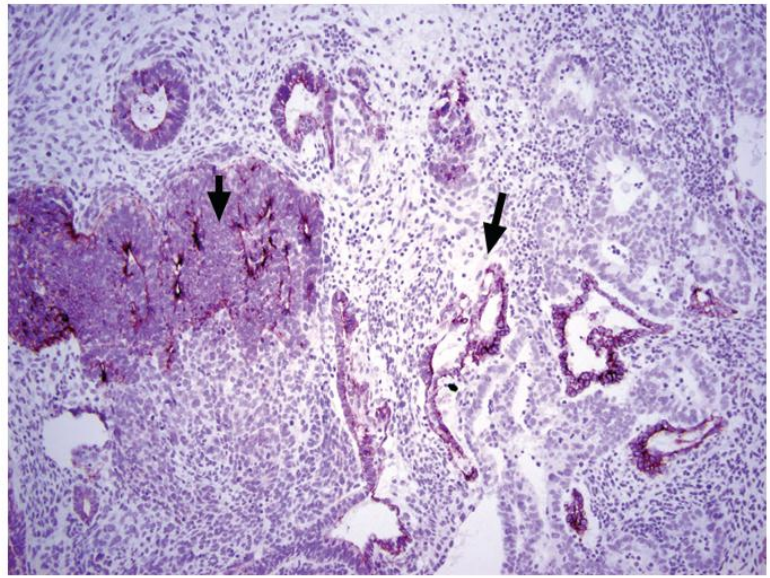

Fig. 9. A: Mixed germ cell tumor consisting of immature teratoma with neuroectodermal elements (short arrow), yolk sac tumor (long arrow), and enteric glands. (H\&E x 20). B: same field (anti N-cadherin $\times 20)$. The neuroectodermal elements (short arrow), enteric gland, and yolk sac tumor (long arrow) are positive.

\section{$10 \mathrm{~A}$}

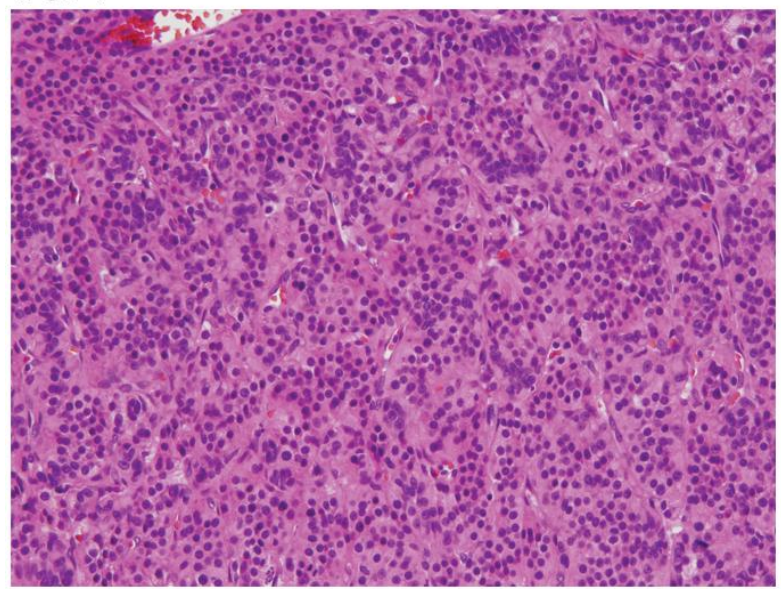

10B

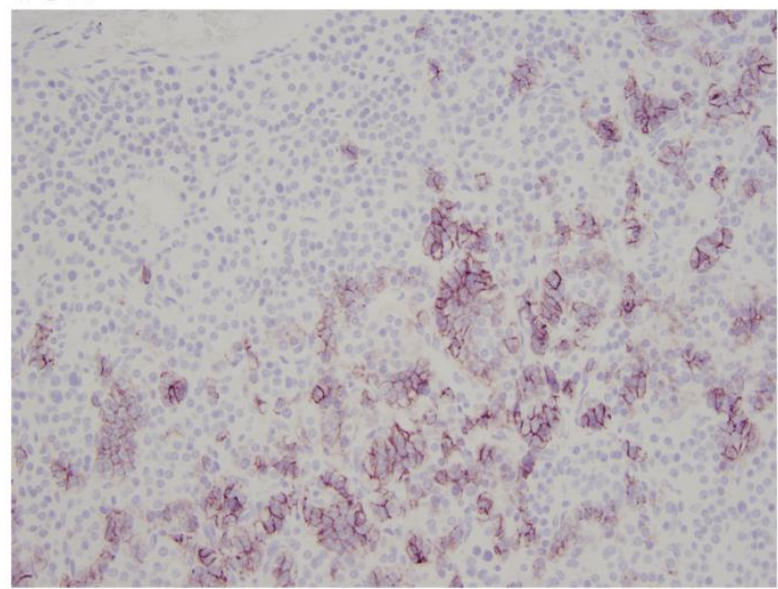

Fig. 10. A: Leydig cell tumor $(H \& E \times 20)$. B: same field (anti N-cadherin $\times 20)$. Note the focal membranous staining. 


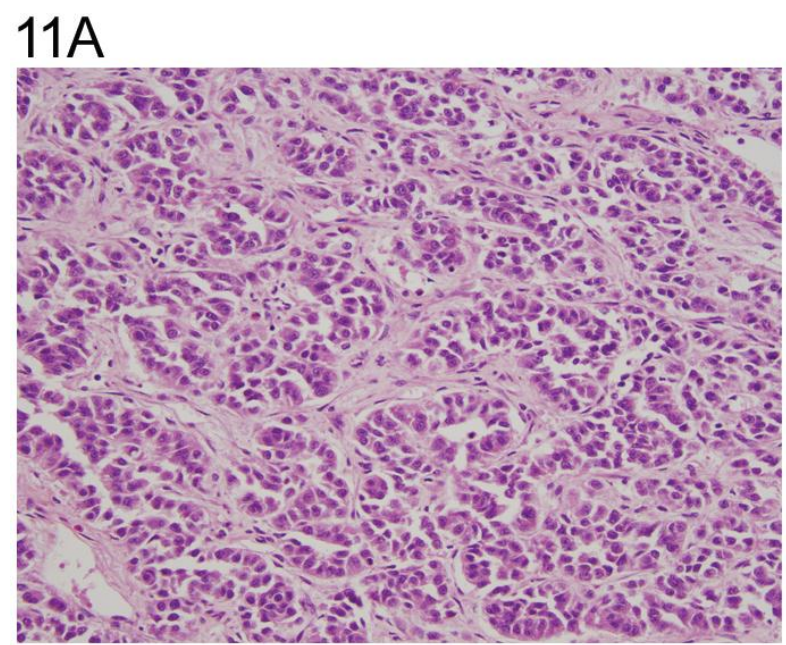

\section{B}

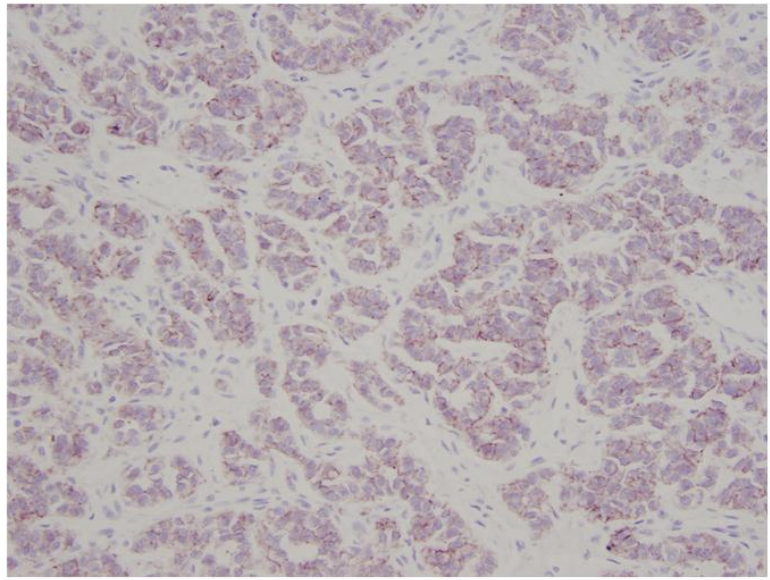

Fig. I I. A: Sertoli cell tumor (H\&E x 20). Note the tubular formation. B: same field (anti N-cadherin). The tumor cells show membranous staining.

$12 \mathrm{~A}$

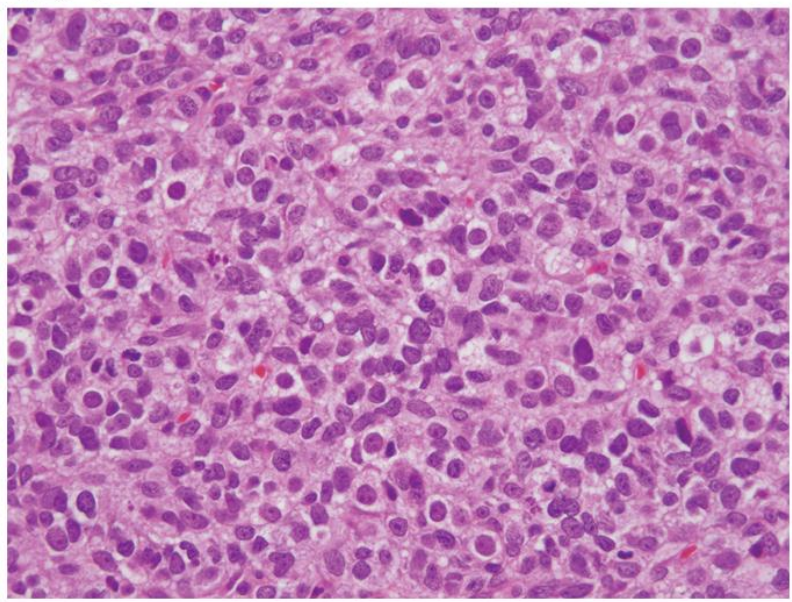

$12 \mathrm{~B}$

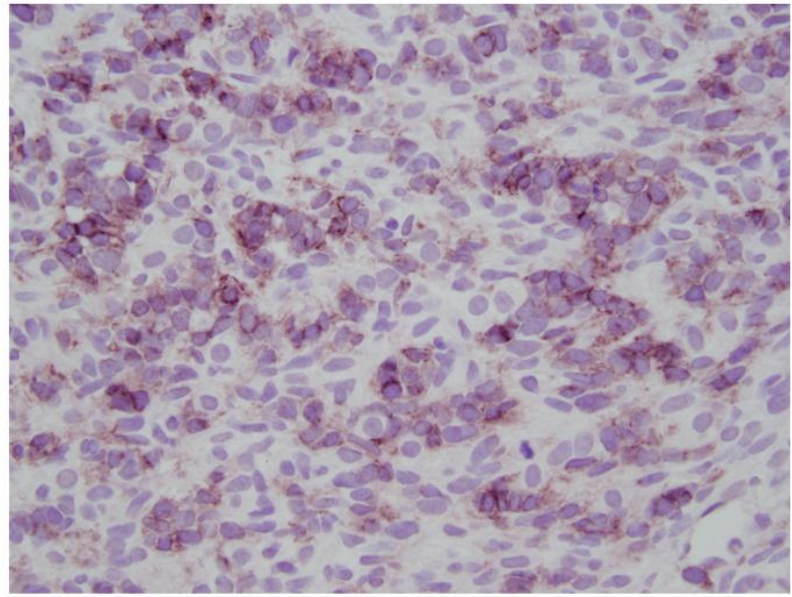

Fig. 12. A: Juvenile granulosa cell tumor (H\&E x 20). B: same field (anti $\mathrm{N}$-cadherin). The staining is membranous and cytoplasmic. 